\title{
Folkism and Modern Nigerian Theatre: A Study of Sam Ukala's Iredi War
}

\section{*Emmanuel A. EREGARE}

\begin{abstract}
Ever since the advent of the modern Nigerian drama and theatre there has been the search for an authentic African form of drama, one which can bridge the divide between the oral performances of traditional African theatre and literary drama of the western mould. Wole Soyinka, Ola Rotimi, Femi Osofisan, Biodun Jeyifo and many other African theorists and writers have tried to proffer solutions to that seeming large problem. Consequently, several theories and dramatic formats have emerged. One of such theories is Folkism formulated by Sam Ukala. This article joins in the search by looking at Sam Ukalaôs Folkism to see whether it adequately solves the problem. It looks at the theory and how best it could be staged. Using the folk script Iredi War as a model, the paper deploys content analysis and participant observation methods to argue that the model is a landmark development in modern African theatre. Hence, it posits that with constant application all the shortcomings would be overcome and the answer to a truly African theatre would have been found.
\end{abstract}

Keywords: Folkism, Folktale, African/Nigerian theatre, Sam Ukala, Iredi War

\section{Introduction}

The argument has been whether there is theatre in traditional Africa or not. They say drama as we see it today originated from the contact of the Africans with the white man. They say our traditional forms at best can only serve as religion. This debate formed the larger part of Yemi Ogunbiyiôs book on Nigerian drama and theatre. The debate dwelt on the presence or absence of drama

*Emmanuel A. EREGARE of the Department of Theatre and Media Art

Ambrose Alli University, Ekpoma_ Email:emaregs@gmail.com 
in traditional African ritual displays. J.P. Clark (now Clark Bekederemo) explained that as the roots of European drama date back to festivals of Egyptian Osiris and Greek Dionysus so also the origins of Nigerian drama are to be found in the early religious and magical ceremonies and festivals that abound in Nigeria (1981). Although Ola Rotimi agrees that there are certain aspects of the ritual displays that can be called drama, those spectacles without elements of mimesis and without plot and suspense and conflict are not (1981). M.J.C. Echeruo then claims that there are dramatic limitations in Nigerian ritual displays and unless they yield their stories (1981). Ossie Enekwe disagrees, saying that in Nigerian ritual displays there are a lot of drama and theatre as the religious tone surrounding these festivals is no longer there (1981).

If the argument cannot be settled as to the presence of theatre in Nigerian festivals, some other scholars tried to look for the answer in other dramatic forms. Andrew Horn argues that any structured performance before an audience whether it is drama, dance, musical recital, group ritual, secular ceremony and even lecturing, is theatre. Quoting E.T. Kirby, he gives seven categories, namely: $\tilde{n}$ (1) simple enactment (2) ritual and ritualized enactment (3) story telling performances (4) spirit cult enactment (5) masquerade and masquerade enactments (6) ceremonial performances (7) comediesò (1981). He reiterates that most of the divisions are merely spectacle and less of drama. He went on to distinguish between drama and religion and between drama and theatre. All these arose because of the desire to place African or Nigerian drama within the mould of European drama and theatre. One may be tempted to agree with the above categorisation but this will put almost all activities where people are gathered in Nigeria to be theatre. However, some of these activities could be said to be, because if It has been alleged by A. Bodunrin, Oyin Ogunba, Bode Osayin and Biodun Jeyifo, among others, that the plays, written in English, by Nigerian literary playwrights are usually unpopular with the Nigeriaôs socioeconomic problems. The unpopularity of the Nigerian literary plays has been attributed by these critics, mainly to language: (i) the language is foreign and illiterate 
Nigerians do not understand it; (ii) it is deliberately made too difficult for the average literate Nigerian to comprehend. The criticism that the plays are ineffective in helping to tackle Nigeriâ socio-economic problems is expressed in three main ways: (i) subject matter does not reflect the recent history and current aspirations of Nigerians and is, therefore, irrelevant; (ii) subjectmatter may be rooted in Nigeriaôs history and culture but it is often distorted beyond the recognition and appeal of the Nigerian masses, as a result of which values are lost which the plays were intended to communicate; (iii) subject- matter may be rooted in Nigeriaôs history and culture and may not even be distorted beyond recognition, but it may be presented in such a foreign or unfamiliar manner as the generality of theatre is play or entertainment there are a lot that in Africa.

The above argument has arisen because of the non-literary form of traditional Nigerian theatre which is largely oral. Beyond the oral traditional form of theatre, there is still the search for an authentic African theatre written by Africans and that could be read and performed. The literary theatre was said to have taken roots in the drama school of the University of Ibadan, though there had been several performances and written plays before then (Ogunbiyi, 1981). The question has been whether the literary theatre is purely African without much influence of Western forms. The first generation writers such as Wole Soyinka, J. P. Clark and Ola Rotimi had been accused of kowtowing to European Aristotelian principles of drama and theatre. However, from this period there had been a desire to formulate a purely Nigerian literary theatre, one that will not only discuss the issues relevant to the people but uses theatrical forms that are close to them. Biodun Jeyifo (1981) opines that the early literary drama was not popular with the people as compared to the theatre of Hubert Ogunde, Ojo Ladipo and others that were derived from the performance patterns of the people. There is the need, therefore, to break the schism and bring the people at par with the theatre. The problems of those plays may have arisen because of the language the plays were written and the style of staging. Jeyifo adds that: 
The real significance of this important critical perception is that the union of western-oriented textual dramaturgical modes with our own indigenous techniques must become a conscious attempt to achieve greater directness, greater clarity, and greater popularity (1981).

Ugwu and Orjinta (2013) record a lot of comments by scholars like Ossie Enekwe, Ahmed Yerima and Sam Ukala on the irrelevance of the early literary drama and call for a relevant theatre. They even quoted Ukala to the effect that:

Nigerians may not identify with.

Over these years, there has been a critical development in African theatre to bridge the lacuna between the literary and the popular theatre but has there been a form of literary theatre that captures the nuances of traditional African performances? Should this kind of theatre have the ñspiceò of traditional performances yet discussing contemporary issues? Some theories have been propounded to chart a way forward in this regard. Ugwu and Orjinta further discuss Soyinkâ̂s mytho-poetic approach, Emeka Nwabuezeôs masquerade dramatic theory, Sam Ukalaôs folkist theatre and Ola Rotimiôs paralinguistic and traditionalist approaches as examples of African theatre theories (2013). As well, there has been the Facequerade theory by Sunnie Ododo, which is derived from observing the dramatic forms of the Ebira people of Kogi State of Nigeria (Ododo, 2008; Omoera, 2012). How well can we say these theories of the written theatre have helped in the development of African theatre in Nigeria? Sam Ukalaô Folkism is one of the several African theories that try to carry over the dramatic and theatrical forms from the traditional arena to the modern literary stage.

\section{What is Folkism}

E. T. Kirbyôs classification as stated above may have been too general but it provides a clue that there are theatrical forms in traditional Africa. With these categories there are also, among 
others, the story telling and storytelling performances. This is the telling the tales of the people which is called folktale. The folktale is part of the oral performance art of the people. The Dictionary.com (2016) defines the folktale as ña story originating in popular culture, typically passed on by word of mouth. Abdul Naôllah (1994) asserts that the ñfolktales are stories told at moonlight. The older members of the community gather the children and teach them about various matters of life. These stories, which the Hausa call Tatsunoyi and the Yoruba Alo are folktales.ò He also calls these stories as ñie storiesò since they are usually fictitious. Ukala (1999) defines the African folktale as ñany traditional oral narrative that is purely fictional or is based on factual history which has however been so embellished and distorted that it cannot be fruitfully subjected to any empirical proof or verificationò. He argues that the folktales include the epic, the legend novella, marchen, saga animal tale, fable, anecdote, among others.

Beyond moonlight tales, folktales in Africa are performed in special occasions and ceremonies. They are sung by griots and minstrels that abound in the land. Isidore Okpewhoôs edited volume discussed several oral performance modes in Africa many of which are the performance of folktales. Ropo Sekoni (1990) in that collection, discusses the rendition of two tales The Story of Two Wives and the The Tortoise and the Iroko Tree. The Ozidi Saga was also dealt with by Okpewho (1990). We have gone to this extent to talk about the folktale because it is the bedrock for the literary theatre created by Sam Ukala called Folkism. The folktale as we have identified is an oral performance that is based on the stories of the people. They could either be tales about ancestors, spirits, animals and inanimate objects which help to teach morals, values and the way of life of the community. The source of this theatre is not a script but the ability of the performers to remember the tales in the communityô oral repertories or the performersô dexterity to weave out new stories from the environment.

This is proven in the robust nature in which they present their tale to their audience who at times already know the tales or 
are conversant with the nuances of the technique of the storyteller so they are able to join in the performance. The modern African theatre, however, is based on the written script - drama. This is exactly what Folkism does. It presents the best way to create drama and the performing of it that will most suitably capture the real African mode of performing the folktale. Folkism according to its creator, Sam Ukala, is: An emergent aesthetic principle ... the tendency to base literary plays on the history, culture, and concerns of the folk é and to compose and perform them in accordance with African conventions for composing and performing the folktale noted for its clear communication and its popularity among the folk, among the many reasons why it should provide a matrix for folkism (qtd in Akpuda, 2008).

The folktale is a means of communicating a message to an audience in a special way that the audience feels and becomes part of the story telling process. Sekoni, using Broderickôs view on oral narratives, opines that to communicate in this way, the narrative pattern is manipulated for the purpose of passing meaning and attaining aesthetic experience. To him then the aesthetics experience in oral performance is made up of three inseparable components: ñcaptivation of audience, retention of audience and the transfer of cognitive experience to the audience. These elements are inseparable; they can only survive in their being togetherò (Sekoni, 1990). These three inseparable components are what make the folktale unique. The performer catches the attention of the audience from the beginning and sustains it till the end of the play. This, however, is not enough as it does not cover a very important aspect of African theatre - audience participation. This and other flaws informed the creation of Folkism. Justifying his proposal for Folkism as a measure for aesthetic enhancement, Ukala further avers that:

There are three main reasons why the African folktaleseems to provide the matrix for such an experiment:

i. the folktale and the conventional literary play are narratives which are ultimately realized in performance; 
ii. in performance, the folktale and the play are temporal, mimetic, interpretive and synthetic; and

iii. unlike other traditional artistic performances in Africa, the folktale, like the play, entails much speech. It is now for the Nigerian literary playwright to study deeply the techniques of the African folktale and to, subsequently, test our hypothesis in his next play

(Ukala, 1993).

Ukala did not just get up and promulgate a theory of theatre he researched into the works of other writers before him. He found out that not all plays derived from the folktale are folkist plays. According to him:

Surely, J.P. Clark in Ozidi, entrenched some techniquesof traditional African folktale performance $i$ the opening and closing formula; the use of narrator; audience-involvement; preserving the identity of a source while adapting new experience to it, the use of the simple plot structure; familiar but artistic diction; advancing the story through the repetition of similar events and leitmotifs. In this, Clark (now Clark Bekederemo) compares favourably with Efua Sutherland in The Marriage of Anansewa, which strongly reflects the Akan techniques of composing and performing folktalesé .Apart from popularity and effectiveness, an indigenous dramatic aesthetic principle, which may be called ófolkismô may derive from the use in the African literary theatre of folk linguistic, structural and performance styles (Ukala, 1993). 
After studying several folktales and works by writers that have written drama from folktales, Sam Ukala came up the eight laws of aesthetic response which if applied the folktale would do better as a literary text. The laws are:

1. the law of opening;

2. the law of joint performance;

3. the law of creativity, free enactment and responsibility;

4. the law of judgment;

5. the law of protest against suspense;

6. the law of expression of the emotions;

7. the law of ego projection; and

8. the law of closing (Ukala, 1993).

The folkist play usually starts with an arresting action and most times with song which gives the audience an incline of what the tale is all about, that law of opening leads to involving the audience in the unfolding tale. It should be noted that this is not a one man narrative folktale rendition but a drama of action with actors taking up roles in the story. The narrator weaves the tale and he or she is also part of the action on stage.

The second law, joint performance is very important as this is what makes African theatre unique. In the folkist theatre the device that has been used to involve the audience is to create characters called MOA (Members of Audience). These are actors who have been rehearsed for their roles and put as part of the real audience. They interject from the audience into the conversation of the actors and also engage them in a questions and answers akin to the Greek chorus. The MOA after a while emboldens the real audience who today had been adulterated with western detached mode of seeing plays, to be involved in the on-going performance.

The third law is that of creativity, free enactment and responsibility, which allows the narrator and the actors to freely interpret the script the way they choose. They are, of course, held 
liable for their actions. The narrator or actor uses his or her voice to add colour to the action. This law from this writerôs experience starts from the inputs of the director as his or her creativity in allowing several elements on to the stage is his or her responsibility. The actors themselves are free agents that add their own ingenuity to the performance and if they over act or do not say something correctly, they are punished instantly by the audience.

The fourth, fifth and seventh laws deal with audience and their ability to get something out of the encounter with the play. The African audience is never silent, they give instant judgement if they like the play or not. Neither had they talked if the actors are not perfuming well. If the play drags or the suspense is too long they would moan or sigh to show their displeasure. There is usually an open display of emotions when the play is liked or disliked. There is an instance when a member of the audience went on stage to spray money on an actor during the performance of Akpakaland directed by this writer. Sam Ukala also recounted a governor engaging a performer in a production of The Last Heroes (1993)

The message of the folkist play is almost felt instantly as the element of immediacy and freedom to talk back is there though limited compared that of the theatre for development. The audience supported by the MOAs sees themselves as part of the performance and they can sing along and even dance along with the actors on stage. This is the ultimate goal of folkism.

\section{Iredi War, a Folk Script}

Sam Ukala has written several plays among, which are Slave Wife, Akpakaland, The Placenta of Death among others. All these plays have folkist tendencies. Iredi War is a little different since it is written out of history and not a made up story or dieôstory as is found in most folktales. The story for the play is a true event that took place in Owa kingdom during the colonial time. The play is in the ilk of Oba Ovoramen Nogbaisi by Ola Rotimi which tried to chronicle the happenings in 1887 when the British sacked the Benin kingdom. This is not the first time Ukala is writing a true tale; he did that with The Odour of Justice which represented the 
travails of Obiamaka Elema. However, the difference is that the latter play was not written in a folkist style.

Iredi War like Akpakaland starts with the narrator (though there are two narrators here). They (the two narrators) provide the direction the play takes and fulfils the first and second folkist laws of aesthetic response: the law of opening and the law of joint performance. In the play the MOAs get involved in the performance from the beginning as they interrogate the two narrators who are also carriers and runners in the office of Crew Reed.

The story of the play as we have noted above is derived from a true life event: the punitive expedition of the British army on the Obi of Owa in 1906. Crew had visited and asked for more taxes and able bodied men to serve as carriers and runners. The people remind him that those who were taken in the past have not returned so they are not inclined to honour his request. The brash, arrogant and inexperienced Reed (called Iredi by the people) will not take ónoôfor an answer. However, a meeting was agreed for the following day by $5 \mathrm{pm}$ for further deliberation. By 12 noon the shrines in Owa were burnt by overzealous new converts. There is now acrimony between the two sides. Instead of handling it well Iredi wants to stamp his authority under the principle of indirect rule being practised by the colonial masters by humiliating the king before his subjects. The altercation that ensues leads to the killing of Iredi. The British without investigating the matter well sends armed men to sack the palace of the Obi of Owa. Obi Igboba was tricked into the courts of Chichester for a peace meeting and was instead arrested. Chichester tries to make a deal with him for his freedom but like a messiah the Obi prefers to go to prison with his people.

That is the story that Ukala weaves into a folkist tale, utilizing all the laws. The opening is fast and laced with songs and dances as in most African plays. The play is seamless; at first glance one would think it is a film script until you understand that a folktale has no barriers of set changes and scenes and acts it a straight performance though divided into three parts. This play like 
all folkist plays by Ukala is an excellent reads but better appreciated in performance.

Folkism in Performance

Theatre is oral performance so says Sam Ukala (Adagbonyin, 1998). That means it goes beyond the script. The very essence of it lies in the performance before an audience. This is exactly what Oscar Brockett (2004) means when he says the three elements that make up theatre are: what is produced which is the script or drama, the performance or those óngredientsôthat are organized together to create the show, and the audience the receiver of the final form called theatre. In oral performance what is produced is not a written script. That is what makes it very critical because the actors must have to do their utmost best to communicate to the audience their message and the style of the folktale performer is apt for that. This, as we have identified above, is the element that Folkism brings to literary drama.

Iredi War though is a folk script deals with a real life story and its performance, as recommended by the author, happens on a thrust stage with permanent sets of the Obi Igbobaôs palace, office of the army area command which later becomes district commissionerố Agborôs office, Irediôs camp and the road to Owa nta. This forms the sets where the action takes place but in actual performance the director is at liberty to alter the arrangement which is what this writer did when the play was performed at Ambrose Alli University, Ekpoma in 2015.

This author has directed or participated in the production of some of Ukalaôs plays among which are The Slave Wife (1998, 2005); The Log in Your Eyes (1998); Break a Boil (1999); The Odour of Justice then The Trial of Obiamaka Elema (2001); Akpakaland (2003 and 2009); and Iredi War (2015) so he has some experience in the production of a folkist play. A very important thing to remember is not to be caged in the confines of the stage like the proscenium or thrust. In the production of Iredi War the whole auditorium was utilized as warriors, soldiers, runners and carriers go into the aisle and come out. This provided a smooth blend of the story and the action. There was also the use of the freezing technique to cover up for the absence of proper lighting 
since the play was done in the afternoon. The bottom line is that the performance must look like the folktale which has no barriers.

This takes us to a very important aspect the stage in which the folkist play could be performed. Uwadima-Idemudia (2013) did an extensive study on the performance area of the folkist theatre and recommends a stage with two round sections joined by a walk way. This is very lofty as it will allow the actors to move freely within the audience from one round part to the other. However, my concern is that of the practicality of that type of stage. The ability of the audience to see all of the action is a problem and that type of stage may be difficult to build unless we say that the folkist theatre can only be an open air affair. The nature of the stage if built may be difficult for other types of plays to be performed in it.

We posit that the folkist theatre is a flexible theatre that can be done anywhere provided the producers fulfil the third law of Folkism: creativity, free enactment and responsibility. Be that as it may, this writer feels that the folkist theatre could best be achieved in the round. Theatre in the round provides the actors and the audience a better opportunity to engage one another. It also gives a better space for a free, flawless movement. We end with the eighth law: The law of closing. Whether in the performance or just being read, the folkist play leaves a note of caution or hope or a plain moral in the mind of the audience. In Iredi War, it ended with a note of caution and hope.

\section{Conclusion}

We have tried to present the position of African theatre in Nigeria and how Folkism has been touted as truly African form of theatre that will marry the traditional forms with the written theatre, thereby making the all audiences to get the feel of what theatre in Nigeria is. In spite of its bold move as a beacon of hope, one cannot fail to state that in practice there are aspects that are akin to the Greco-western theatre. The language of its rendition and the format of production space leave a smack of western influence on the creator (Sam Ukala) of the theory. We recommend, therefore, that though Folkism is a bold attempt at addressing the question of the gap between the traditional forms and literary theatre in modern Africa it should constantly be engaged by theatre practitioners (writers, directors and producers) for the theory to be improved upon. 


\section{References}

Adagbonyin, A. S. (1999). Creative truth is immutable: Interview with Prof Sam Ukala. In Steve Ogunde, Benji Egede and Amen Uhunmwangho (Eds.), Eagle in flight: The writings of Sam Ukala. Ibadan: Safmos Publishers.

Akpuda, A.A. (2008). Sam Ukala as a theorist of the African alternative theatre tradition. In A.O. Asagba (Ed.), Sam Ukala: His works at sixty (pp. 15-47). Ibadan: Kraft Books Limited.

Brochett, O.G. (2004). The essential theatre (7tth edition). New York: Wadswworth Publishing.

Clark, J.P. (1981). Aspects of Nigerian drama. In Y.Ogunbiyi (Ed.), Drama and theatre in Nigeria: A critical sourcebook (pp. 57-74). Lagos: Nigeria Magazine .

The Dictionary.com (2016). Retrieved June 12, 2016, from http://www.dictionary.com/browse/folk-tale

Echeruo, M. (1981). Dramaitc limits of Igbo rituals. In Y.Ogunbiyi (Ed.), Drama and theatre in Nigeria: A critical sourcebook (pp. 136-148). Lagos: Nigeria Magazine.

Enekwe, O. (1981). Myth, ritual and drama in Igboland. In Y.Ogunbiyi (Ed.), Drama and theatre in Nigeria: A critical sourcebook (pp. 149-163). Lagos: Nigeria Magazine.

Horn, A. (1981). Ritual drama and the theatrical: The case of Bori spirit mediumship. In Y. Ogunbiyi (Ed.), Drama and Theatre in Nigeria: A critical sourcebook (pp. 181-202). Lagos: Nigeria Magazine.

Jeyifo, B. (1981). Literary drama and the search for a popular theatre in Nigeria. In Y. Ogunbiyi (Ed.), Drama and theatre in Nigeria: A critical source book (pp. 411-421). Lagos: Nigeria Magazine.

Na'Alllah, A. (1994). Oral literary traditions in Africa. In O. Obafemi (Ed.), New introduction to literature (pp. 101117). Ibadan: Y Books.

Ododo, S.E. (2008). Facequerade: the transformational duality in Ebira-EkwechiFestival performances. Cultural Studies, 22(2), 285-309. 
Ogunbiyi, Y. (1981). Theatre and drama in Nigeria. In Y. Ogunbiyi (Ed.), Drama and theatre in Nigeria: A critical source book. Lagos: Nigerian Magazine.

Okpewho, I. (1990). The oral performer and its audiences: A case study of the Ozidi saga. In I. Okpewho (Ed.), The oral performance in Africa (pp. 160-184). Ibadan: Spectrum Books.

Omoera, O.S. (2012). The significance of Facekuerade theory in contemporary African theatre practice. In O.S. Omoera, S. Adeyemi \& B. Binebai (Eds.), A gazelle of the savannah: Sunday Ododo and the framing of techno-cultural performance in Nigeria, [Volume 1] (pp.63-75). Rochester, Kent: Alpha Crownes.

Rotimi, O. (1981). The drama in African display. In Y. Ogunbiyi (Ed.), Drama and theatre in Nigeria: a critical Source Book (pp. 77-80). Lagos: Nigeria Magazine.

Sekoni, R. (1990). The narrator, narative-pattern and audience experience of oral narative performance. In I. Okpewho (Ed.), Oral performance in Africa (pp. 139-159). Ibadan: Spectrum Books.

Ugwu, I and Orjinta, I. A. (2013). đFolkismô and the search for a relevant Nigerian literary theatre: Sam Ukalâ̂ The Placenta of Death and Akpakaland as Paradigms. Research on Humanities and Social Sciences, 3(13), 79-85.

Ukala, S. (1993). đ́folkismô Towards a national aesthetic principle in dramaturgy. A Monthly International Literary Journal of Writers Resort 79,11-38.

Ukala, S. (1999). ÓMasquerade, Folktake and literary theatre of English expression in Africaô In Steve Ogunde, Benji Egede and Amen Uhunmwangho (Eds.), Eagle in flight: The writings of Sam Ukala. Ibadan: Safmos Publishers.

Ukala, S. (2014). Iredi War: A folk script drama. Ibadan: Kraft Books Limited.

Uwadimma-Idemudia I. E. (2013). From Folkism to performance: A new scenic strategy for audience integration. Ekpoma Journal of Theatre and Media Arts,4 (1\&2). Retrieved June 6, 2017, from

www.ajol.info/index.php/ejotmas/article/download/120647/

110097 